\title{
Desain Sistem Pembangkit Listrik Tenaga Hybrid Diesel Generator-PV Menggunakan Software HOMER (Studi Kasus: KM Barcelona 1 di Pelabuhan Manado)
} Olive Ang Jaya ${ }^{*}$, Hesky Stevy Kolibua ${ }^{*}$,Verna Albert Suoth ${ }^{*}$

aJurusan Fisika, FMIPA, Unsrat, Manado

\begin{tabular}{l} 
K A T A K U N C I \\
\hline Pembangkit listrik \\
hybrid \\
Kapal laut \\
HOMER
\end{tabular}

\begin{abstract}
A B S T R A K
Telah dilakukan penelitian untuk merancang sistem pembangkit listrik hybrid menggunakan software HOMER. Data beban listrik yang digunakan pada penelitian ini diambil dari kapal motor Barcelona 1 dengan rute perjalanan Manado-Tahuna dan data radiasi matahari diambil dari website NASA yang diakses melalui software HOMER. Data-data itu dimasukkan pada software HOMER untuk disimulasikan. Skenario 1 dibuat sesuai dengan kondisi sebenarnya di kapal dan skenario 2 merupakan desain sistem pembangkit listrik hybrid yang menggunakan photovoltaic. Berdasarkan simulasi yang telah dilakukan, desain pembangkit listrik pada skenario 2 lebih optimal dengan nilai NPC (Net Present Cost) yaitu US\$833.174 dan nilai Cost of Energy (COE) yaitu US $\$ 0,406$. Skenario tersebut terdiri dari generator berkapasitas $10 \mathrm{~kW}$ dan panel surya $58,6 \mathrm{~kW}$.
\end{abstract}

K E Y W O R D S

Hybrid power plants Ships HOMER

TERSEDIA ONLINE

01 Agustus 2019

1. Pendahuluan

Indonesia adalah negara maritim yang memiliki luas wilayah lautan lebih besar daripada wilayah daratan, sehingga terdapat banyak kapal yang beroperasi di laut. Kapal-kapal tersebut menggunakan bahan bakar minyak bumi untuk menggerakkan generator listrik (Argianto dan Winarno, 2017). Semakin banyak konsumsi bahan bakar minyak khususnya di industri maritim membuat ketersediaan minyak bumi semakin menipis dan harga bahan bakar minyak semakin tinggi, sehingga dapat mempengaruhi kondisi lingkungan serta ekonomi (Beşikçi, 2016). Oleh sebab itu, pengembangan sumber energi alternatif sangat dibutuhkan untuk memenuhi kebutuhan energi di kapal (Argianto dan Winarno, 2017).

Menurut Erdinc dan Uzunoglu (2012), menggabungkan sumber energi terbarukan dengan sebuah unit cadangan untuk membentuk sistem hybrid, dapat menyediakan listrik yang lebih ekonomis dan ramah lingkungan dibandingkan dengan penggunaan sistem tunggal. (Hendrayana, 2017) telah melakukan penelitian dengan merancang sebuah sistem pembangkit listrik hybrid dengan memanfaatkan generator sebagai daya tambahan, penelitian tersebut mendapatkan hasil persentase yakni pemanfaatan energi terbarukan meningkat dari 11,73\% menjadi $25,94 \%$ dan untuk pemanfaatan generator berbahan bakar fosil

*Corresponding author: Jurusan Fisika FMIPA UNSRAT, Jl. Kampus Unsrat, Manado, Indonesia 95115; Email address: vernasuoth@unsrat.ac.id Published by FMIPA UNSRAT (2019) 
mengalami penurunan dari 24,05\% menjadi 16,74\%. Menurut Soba et al (2019) semakin besar kapasitas energi terbarukan yang digunakan, maka semakin sedikit bahan bakar yang akan digunakan.

Yoga (2018) telah melakukan penelitian studi ekonomi mengenai sistem penyedia cadangan daya hybrid bayu-diesel (studi kasus: Di Hotel Queen Of The South Beach Resort) menggunakan software HOMER (Hybrid Optimization Model for Electric Renewables). Dari simulasi yang telah dilakukan, dapat disimpulkan bahwa kontribusi dari sumber energi terbarukan untuk penggunaan sistem hybrid bayu-diesel sebagai cadangan pembangkit listrik di hotel dapat memproduksi $81 \%$ energi terbarukan dari total energi yang diproduksi.

Sistem pembangkit listrik hybrid pada kapal dapat dirancang menggunakan perangkat lunak HOMER. Perangkat lunak HOMER dapat mensimulasikan semua konfigurasi sistem yang tepat dari berbagai sumber energi terbarukan untuk memenuhi kebutuhan beban dengan daya yang dibutuhkan pada kondisi tertentu dari data yang ada selain ukuran generator diesel yang telah terpasang (Diab, 2016).

Hafez and Bhattacharya (2012) merancang sistem dengan empat skenario berbeda, yaitu hanya diesel, gabungan energi terbarukan, gabungan energi terbarukan dengan diesel, and konfigurasi jaringan mikro terkoneksi ke jaringan luar. Tujuan penelitian ini untuk membandingkan dan mengevaluasi beberapa desain sistem dari segi ekonomi, cara kerja operasional, dan emisi terhadap lingkungan. Dari analisis keempat skenario yang telah dirancang, hasil yang ditunjukkan bahwa skenario 3 (diesel-energi terbarukan) adalah yang paling optimal karena lebih efektif dalam memenuhi kebutuhan beban dan lebih ekonomis.

Menurut Tang et al (2015) penerapan pembangkit listrik hybrid dengan sistem manajemen daya dan energi pada kapal sangat bermanfaat untuk meningkatkan efisiensi energi, meminimalkan konsumsi bahan bakar generator dan juga sekaligus mengurangi emisi gas buang pada kapal.

Sebagian besar kapal laut yang ada di Indonesia masih sangat bergantung pada generator diesel sebagai penyedia listrik dikapal. Salah satu kapal laut di Pelabuhan Manado yaitu KM Barcelona 1 dengan rute perjalanan Manado - Tahuna menggunakan generator diesel berkapasitas 200 kW yang mengkonsumsi bahan bakar solar sebanyak 125 Liter dalam 1 rute perjalanan untuk memenuhi kebutuhan energi listrik dikapal. Pemakaian bahan bakar minyak secara terus menerus akan mengakibatkan kelangkaan sehingga harganya akan semakin mahal dan meningkatnya pencemaran diudara akibat emisi yang dihasilkan oleh generator diesel serta pencemaran pada air laut oleh limbah hasil pembuangan.

Berdasarkan latar belakang tersebut, sangat penting untuk mencari sumber energi alternatif lain yang dapat mengurangi kerja dari generator sehingga bahan bakar minyak yang digunakan akan berkurang. Untuk itu, dalam penelitian ini dibuat dua skenario sistem pembangkit listrik yang akan disimulasikan menggunakan software HOMER, skenario pertama merupakan desain sistem pembangkit listrik yang sesuai dengan keadaan sebenarnya dikapal dan skenario kedua merupakan desain sistem pembangkit listrik hybrid menggunakan photovoltaic dan generator diesel. Dari penelitian ini diharapkan supaya penggunaan bahan bakar pada kapal dapat berkurang sehingga dapat juga mengurangi polutan yang mencemari lingkungan.

2. Bahan dan Metode
Alat dan Bahan
- Laptop
- HOMER software
- GPS (Global Positioning System)
- Digital clamp meter DT-266 (Tang Ampere Digital)
Prosedur

1. Software HOMER dibuka. Halaman depan software HOMER dapat dilihat pada Gambar 1.

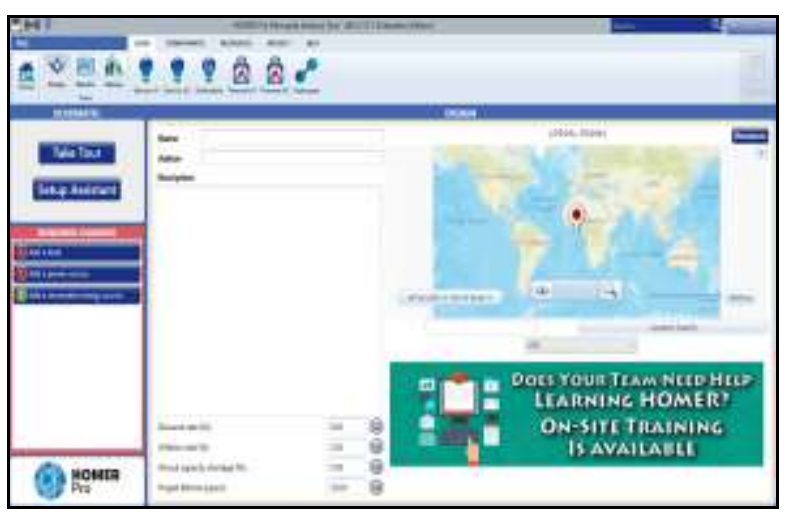

Gambar 1. Halaman awal software HOMER

2. Data beban dari KM Barcelona 1 dimasukkan ke tabel beban listrik dan data radiasi matahari didownload dari NASA melalui software HOMER.

3. Komponen-komponen dipilih sesuai skenario yang akan dibuat. Skenario pertama merupakan keadaan sebenarnya pada KM Barcelona 1 yang terdiri dari generator $200 \mathrm{~kW}$ dan skenario kedua merupakan desain sistem pembangkit listrik hybrid yang terdiri dari generator $10 \mathrm{~kW}$, baterai, photovoltaic, dan konverter. Skenario 1 dan 2 dapat dilihat pada Gambar 2 (a) dan (b).

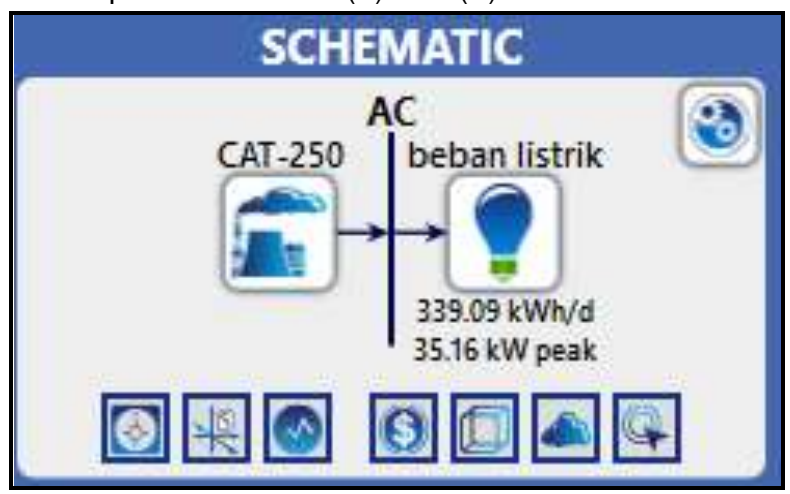

Gambar 2. Skenario 1 (kondisi sebenarnya) 


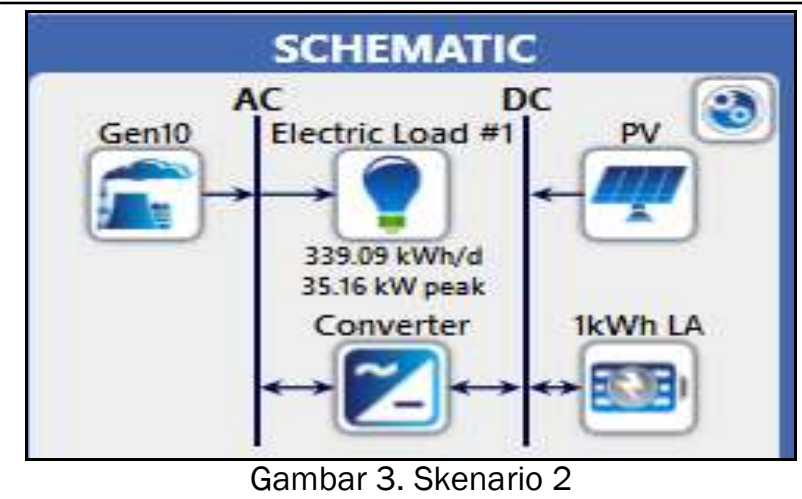

3. Hasil dan Pembahasan

Beban Listrik

Dari Gambar 3 dapat dilihat bahwa beban listrik pada KM Barcelona 1 berada dipuncak pada jam 19.00 sampai 05.00 karena pada jam tersebut kapal sementara berlayar sehingga membutuhkan banyak daya untuk memenuhi kebutuhan beban listrik.

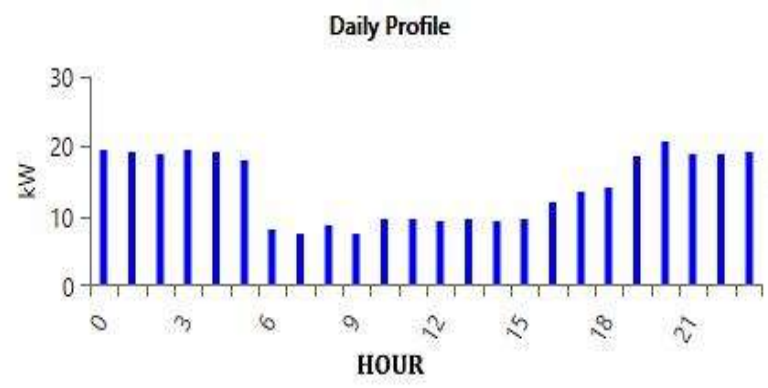

Gambar 3. Profil beban pada KM Barcelona 1

\section{Data Radiasi Matahari}

Data radiasi matahari diambil dari website NASA Surface Meteorology and Solar Energy (SMSE) dengan memasukkan titik koordinat pelabuhan Manado. Rata-rata radiasi matahari pertahun pada wilayah ini yaitu $5,91 \mathrm{kWh} / \mathrm{m}^{2} /$ hari. Gambar 4 menunjukkan profil radiasi matahari selama 1 tahun.

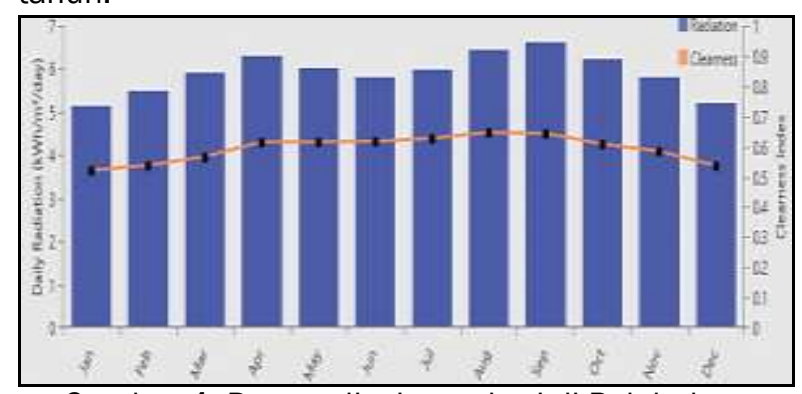

Gambar 4. Data radiasi matahari di Pelabuhan Manado

\section{Hasil Simulasi}

Pada skenario 1, energi listrik bersumber dari generator $200 \mathrm{~kW}$. Konfigurasi sistem pada skenario 1 merupakan kondisi sebenarnya pada KM Barcelona 1. Skenario 2 terdiri dari generator diesel $10 \mathrm{~kW}$ dan panel surya. Tabel 1 menunjukkan kapasitas komponen-komponen yang digunakan pada skenario 1 dan 2 .
Tabel 1. Komponen yang digunakan pada Skenario 1 dan 2

\begin{tabular}{lcc}
\hline \multicolumn{1}{c}{ Komponen } & Skenario 1 & Skenario 2 \\
\hline Generator, kW & 200 & 10 \\
\hline PV, kW & - & 58,6 \\
\hline Konverter, kW & - & 23,6 \\
\hline Baterai, jumlah & - & 376 \\
\hline
\end{tabular}

Dari hasil simulasi yang dilakukan, skenario sistem yang paling optimal adalah skenario 2 karena memiliki nilai NPC paling rendah jika dibandingkan dengan skenario 1 seperti terlihat pada Tabel 2. NPC merupakan total biaya yang harus dikeluarkan selama masa proyek. Biaya terbesar yang harus dikeluarkan pada skenario 1 adalah biaya bahan bakar untuk generator karena skenario 1 hanya menggunakan generator saja untuk menghasilkan energi listrik. Pada skenario 2 biaya pengadaan dan penggantian sangat besar karena pada skenario ini menggunakan generator $10 \mathrm{~kW}$ dan panel surya sehingga kapasitas panel surya yang digunakan dan baterai menjadi besar untuk memenuhi kebutuhan energi listrik yang dibutuhkan. Rincian biaya untuk skenario 1 dan 2 dapat dilihat pada Tabel 2 .

Tabel 2. Perbandingan parameter ekonomi pada Skenario 1 dan 2

\begin{tabular}{lll}
\hline \multicolumn{1}{c}{ Parameter } & \multicolumn{1}{c}{ Skenario 1 } & \multicolumn{1}{c}{ Skenario 2 } \\
\hline NPC, US\$ & 1.534 .564 & 833.174 \\
\hline COE, US\$/kWh & 0,7470 & 0,4028 \\
\hline $\begin{array}{l}\text { Operating cost, } \\
\text { US\$/year }\end{array}$ & 91.516 & $33.848,8$ \\
\hline Initial capital, U\$ & $15.518,8$ & 271.327 \\
\hline Replacement, U\$ & $29.838,5$ & 259.679 \\
\hline O\&M, U\$ & $7.270,2$ & 108.845 \\
\hline Fuel, U\$ & 1.484 .271 & 205.471 \\
\hline Fuel, L/yr & 156.879 & 21.717 \\
\hline
\end{tabular}

\section{Produksi Energi Listrik}

Tabel 3. Perbandingan kelistrikan pada skenario 1 dan 2

\begin{tabular}{lll}
\hline \multicolumn{1}{c}{ Parameter } & Skenario 1 & Skenario 2 \\
\hline $\begin{array}{l}\text { Electrical } \\
\text { Production,kWh }\end{array}$ & 438.000 & 165.852 \\
\hline $\begin{array}{l}\text { Excess } \\
\text { Electricity,kWh/yr }\end{array}$ & 314.232 & 28.543 \\
\hline
\end{tabular}

Tabel 3 menunjukkan produksi energi listrik dari dua skenario sistem yang telah dirancang. Energi listrik pada skenario 1 berasal dari generator diesel $200 \mathrm{~kW}$ dengan produksi energi listrik 438.000 $\mathrm{kWh} /$ tahun, kelebihan listrik sebesar 314.232 $\mathrm{kWh} /$ tahun atau $71,7 \%$ dari total energi listrik yang diproduksi. Kelebihan listrik yang dihasilkan akan merugikan jika tidak disimpan dalam baterai atau tidak ada beban listrik tambahan.

Produksi energi listrik dalam skenario 2 berasal dari generator $10 \mathrm{~kW}$ dan PV 58,6 kW. Listrik yang dihasilkan oleh generator diesel adalah 64.909 $\mathrm{kWh} /$ tahun atau $39,1 \%$ dan PV adalah 100.943 $\mathrm{kWh} /$ tahun atau $60,9 \%$ dari total produksi energi 
listrik sementara kelebihan listrik dalam skenario ini adalah $28.543 \mathrm{kWh}$ /tahun atau sekitar 27,3\%.

\section{Perbandingan Emisi Lingkungan Dari Berbagai Skenario}

Tabel 4. Perbandingan emisi dari skenario 1 dan 2

\begin{tabular}{cccc}
\hline Polutan & $\begin{array}{c}\text { Skenario 1 } \\
\mathrm{kg} / \text { tahun }\end{array}$ & $\begin{array}{c}\text { Skenario 2 } \\
\mathrm{kg} / \text { tahun }\end{array}$ \\
\hline $\mathrm{CO}_{2}$ & & 413,77 & 101,93 \\
\hline & $\mathrm{CO}$ & 794 & 196 \\
\hline & $\mathrm{UHC}$ & 17,3 & 4,25 \\
\hline $\mathrm{PM}$ & 40,8 & 10 \\
\hline $\mathrm{SO}_{2}$ & 1.029 & 253 \\
\hline $\mathrm{NO}_{z}$ & 4.115 & 1.014 \\
\hline
\end{tabular}

Salah satu tujuan dari penelitian ini adalah untuk mengurangi emisi dengan menggunakan sumber energi terbarukan sebagai pembangkit listrik hibrida. Hasil yang ditunjukkan pada Tabel 4 menunjukkan bahwa pembangkit listrik dalam skenario 2 sangat ramah lingkungan. Ini karena menghasilkan polutan lebih sedikit dari skenario 1.

\section{Kesimpulan}

Berdasarkan analisis dari dua skenario yang telah disimulasikan, dapat disimpulkan bahwa desain sistem yang paling optimal dan ramah lingkungan adalah desain sistem pada skenario 2 yang terdiri dari generator $10 \mathrm{~kW}$. PV 58,6 kW, konverter 23,6 kW, dan 376 baterai berkapasitas 1 kWh. Nilai NPC pada skenario ini yakni US\$833.174 dan COE US $\$ 0,4028$. Skenario ini mempunyai biaya pengadaan yang lebih besar dibanding skenario 1 karena biaya pengadaan untuk photovoltaic dan baterai yang tergolong mahal, sedangkan skenario 2 lebih irit dalam penggunaan bahan bakar minyak dan lebih ramah lingkungan. Energi listrik yang diproduksi yaitu sebesar $165.852 \mathrm{kWh}$ /tahun dan kelebihan energi listrik pada skenario 2 sebesar 28.543 kWh/tahun.

\section{Daftar Pustaka}

Argianto, R. A dan I. Winarno.2017. Rancang Bangun Pembangkit Listrik Tenaga Hybrid antara Solar Cell dan Thermoelectric Generator (TEG) sebagai Sumber Energi Listrik Di Kapal Nelayan. Seminar Nasional Kelautan XII. C2 : 22-31

Beşikçi, E. Bal., T. Kececi, O. Arslan, O. Turan.2016. An Application of Fuzzy-AHP to Ship Operational Energy Efficiency Measures.Ocean Engineering

Diab, F., H. Lan dan S. Ali.2016. Novel comparison study between the hybrid renewable energy systems on land and on ship. Renewable and Sustainable Energy Reviews.Elsevier. 63: 452463

Erdinc, O. dan M. Uzunoglu.2012. Optimum design of hybrid renewable energy systems: Overview of different approaches. Renewable and Sustainable Energy Reviews.Elsevier. 16: $1412-1425$
Hafez, O dan K. Bhattacharya.2012. Optimal planning and design of a renewable energybased supply system for microgrids. Renewable Energy.Elsevier. 45: 7-15

Hendrayana.2017. Simulasi Sistem Hibrid Pembangkit Energi Surya, Angin, dan Generator Untuk Mengoptimalkan Pemanfaatan Daya Energi Terbarukan. Jurnal IImiah Pendidikan Teknik Elektro. 1(1) : 26-43

NASA. Surface Meteorology and Solar Energy Data. Available: http://www.data.nasa.gov/surfacemeteorology-and-solar-energy. [diakses pada Maret 2019]

Soba, A., V. A. Suoth., dan H. S. Kolibu. 2019. Optimasi Kapasitas Pembangkit Listrik Tenaga Hybrid (PLTH) di Pulau Bunaken Menggunakan Software HOMER.Manado:Jurnal MIPA Online

Tang, D., X. Yan., Y. Yuan., K. Wang., dan L. Qiu.2015. Multi-agent Based Power and Energy Management System for Hybrid Ships.IEEE ICRERA. 383-387

Yoga, T. K. 2018. Laporan Tugas Akhir Studi Ekonomi Sistem Penyedia Cadangan Daya Hybrid Bayu-Diesel (Studi Kasus : Di Hotel Queen Of The South Beach Resort) [Skripsi]. Universitas Islam Indonesia, Yogyakarta 